INSTITUTE FOR THE ADVANCEMENT OF CALVINISM. 1976. The contemporary challenge. Proceedings of the First international conference of reformed institutions for Christian scholarship, Potchefs troom, 9-13 Sep. tember 1975. Potchefstroom University for CHE. $418 \mathrm{pp}$.

This publication presents all the papers read at a conference held at the Potchefstroom University for Christian Higher Education during September 1975. The theme of the conference (initiated by Prof. H.J.J. Bingle, at the time rector of the PU for $\mathrm{CHE}$ ) was formulated as "Reformed Institutions for Higher Education as a Bulwark for the Kingdom of God - present and future". The idea of such institutions as a "bulwark for the Kingdom of God" is toned down in the title of this book. The difference in tone may be explained as the result of the difference between a stage of planning and a stage of looking back on what was carried out of that planning. Such a review of this enterprise cannot be unaccompanied by the feelings of being "sadder but wiser". Something of this is reflected in the prefatory notes of Prof. Bingle to this book. Experiences of the conference came to be committed to paper in this publication and Prof. Bingle remarks very aptly amongst other things that this collection of conference papers reveals a probable "identification of important differences of opinion on Christian lligher Education." But if this insight meant a revision of the idea of institutions for Christian higher education as "bulwarks for the Kingdom of God", this publication also serves to put on record another experience of the conference: "that there are encouraging signs of a will to find one another in our common pursuit of an honest appraisal of the Christian principle in higher education". These proceedings may be viewed (in the words of Prof. Bingle) as a valuable expression and documentation of an "attempt at ecumenicity within the context of Christian Higher Education".

Delegates to this conference represented 76 different institutions in 19 countries on all the continents. From the African continent papers were read by delegates from Kenya and South Africa; Asia was represented by papers from South Korea, Japan and Indonesia. Europe was very well represented by papers from the United Kingdom, France, Germany and (their zeal for discussion apparently not handicapped by their unskilled use of the English tongue) from the Netherlands. America's presence was also made known, and papers by delegates from Australia and South America complete the list. 
The first eight papers deal with problems relating to the university as a centre for Christian higher education. Prof. H.JJ. Bingle's paper, $A$ radical new order? centres around the question as to whether the Christian institution needs a new structure at a time when most neutral universities are experiencing a crisis in their aims and organization. His answer is that the Christian university is not in search of a "new, unknown, radically different order in higher education, but we are aiming at the perfection of that which has been developed by generations and which may sometimes appear to the uninitiated as a radically new design" (p. 21). This rather uncritical assessment of the university's tradition is counterbalanced by Prof. H. van Riessen (Amsterdam) with a paper titled The university as it is and as it ought to be. Amongst other things he underlines the contribution of a long tradition of a striving for autonomous thinking to the present crisis of the university. In a paper written with compassion Prof. Pierre Courthial (Aix-en-Provence) outlines Threats to the Christian character of the Christian institution. One of the current concerns of the conference was formulated by him as follows: "The Christian character of an institution, in fact, demands a fraternal communion of prayer, thought, and sharing of enterprise, to which numbers are inevitably a threat" (p. 53). Prof. J.H. Kromminga (Grand Rapids) focusses on other threats to the Christian character of an institution for Christian higher education, such as the growing difficulty of a unified worldview, disunity and diversity in Christian higher education, confessional inadequacies, problems related to the interpretation of the Bible, and financial pressures. In this paper Prof. Kromminga expresses a crucial matter: "The historic confessions on which many schools base their work are three to four hundred years old. Sound though they are at the core, they do not address today's situation at many crucial points. They contain little recognition of the minority role of the Christian community in a secularized world. (...) Perhaps the confession called for should not be a new church confession, but some kind of creed for the academic community" (p. 63-4).

In a broadly conceived paper Prof. H. Hart (Toronto) outlines and explores The idea of Christian scholarship. His own position, which is meant to be a critical assessment of the Western idea of scholarship, may be summarized as follows: "Stating definitions is what defines scholarship. Something is defined when we can state the limits within which it maintains its continued identity during the time which it essentially remains what it is. (...) The limits discovered and stated by the scholar are in Scripture proclaimed to be God's ordinances; provided, of course, that the scholarship is carried on in truth" (p. 84). Prof. Hart's paper is one of a few papers in this collection which reflect some of the issues debated during the conference, and serves as an indispensible indicator of the diversity of opinions among scholars of 
the Calvinist Reformed tradition. Prof. Henry Stone of Pretoria's lecture Contextual possibilities for Christian academic training is a very careful elaboration on a theme of Prof. Hart's lecture, viz. "fundamentally Christian scholarship through the university should be seen as a service of reconciliation" (p. 102). Dr. Z. Rittersma (the Netherlands) deals with The national and international structure and task of the Christian institution for higher education. This paper unfortunately leaves one with the impression that much historical ground (relating to Calvin and Kuyper) has been covered, without a proper clarification of the issues at stake with the "national and international structure" of the Christian institution for scholarship. A very brief outline for such an eventual clarification is suggested in Propositions for a discussion on the same topic, formulated by Prof. P.G.W. du Plessis (Johannesburg) and Dr. B.J. van der Walt (Potchefstroom). The relevance of these propositions is severely limited, however, because nothing of the ensuing discussion of these propositions is included in this collection by the reconnaissance committee.

The two papers by Prof. N. Wolterstorff (Grand Rapids) and Prof. H.G. Stoker (Potchefstroom), taken together with Prof. Hart's paper, make for very interesting philosophical reading. These three papers reflect a very stimulating difference in philosophical style. Prof. Wolterstorff discusses in his paper Commitment and theory the problem "how should a person who is both a Christian and a scholar relate his Christian commitment to his theorizing and his theorizing to his commitment?" (p. 116). With sharply defined arguments and a disciplined reasoning (hallmarks of the AngloSaxon analytical philosophy which Prof. Wolterstorff shares) he expounds the view of the role of commitments in weighing a theory as the role of beliefs. "... The religious beliefs of the Christian scholar ought to function as control beliefs within his devising and weighing of theories. This is not the only way they ought to function. They ought also to help shape his views as to what it is important to have theories about" (p. 122). Our Christian calling of doing science by Prof. H.G. Stoker represents one of the major contributions to this book. Stoker is one of the doyens of Calvinist philosophy in the world, and this paper is the most recent statement of his view of the relation of a world and life view to scientific endeavour - a crucial (and favourite) topic for many Calvinists. In a style reminiscent of the best of the European tradition since Descartes and Leibniz, Prof. Stoker expounds "arguments for our Christian calling of doing science attached to the knowable, specifically to the general truths of the Word of God" (p. 140ff), and concludes this paper with "proofs" for the "necessity of "Christian' science" (p. $152 \mathrm{ff}$ ). The short paper of Prof. J. Chr. Coetzec (formerly from Potchefstroom) ends this section of papers on the problems of Christian scientific endeavour. 
The existential relevance and the international significance of this conference are illustrated in the following nine papers. This section deals with problems confronting the Christian scholar within his specific cultural milieu. The papers of Prof. R. Hashimoto (Japan) and Prof. A.H. Nichols (Indonesia) discuss the problems affecting the development of Christian science and Christian education in non-Christian countries. For any Christian living out his Christian creed in relative comfort it is a chilling experience to hear that in a pagan, industrialized country such as Japan the idea of a Christian university is for various strategic reasons unthinkable. Therefore the idea of Christian scholarship has to be recast as one of controlling the development of science (p. 169) without institutionalizing that idea. And in Indonesia the idea of Christian scholarship rubs shoulders with the Islamic faith.

It was a moving experience - and certainly one of the highlights of the conference - to hear the paper of Prof. S. Rooy (Buenos Aires) on The challenge to reformed higher education in the Latin Third World countries. It certainly makes for penetrating and scholarly literature too! His lecture brought many currently compelling issues to the floor of the conference hall. "Without the contribution of Reformed sociologists, economists, political scientists, anthropologists, psychologists, and others, any theological formulation will be as limited as a second grader's analysis of aerodynamics. Theology is no longer queen of the sciences, it can only aspire to be a humble companion on the road to understanding" (p. 192).

Prof. G. van Groningen (Jackson USA) analyses Problems affecting the development of Christian learning or Christian scholars and Prof. J.A. Heyns (Pretoria) outlines a philosophy of The position of the Christian lecturer, teacher and student at a Christian institution with specific reference to the educational task. Prof. T. Kodera (Japan) deals with much the same problem in his paper, but focusses on the situation in Japan as a nonChristian country.

Prof. W.S. Reid of Ontario's good-humoured paper on The Christian in the secular university concludes compellingly: "Christians today must move into the secular institutions if they would bear witness in one of the most important spheres of our western culture. Christ gave his marching orders to his church to go into all the world and preach the Gospel to every creature. Unless the Christians do this in the secular institutions of higher learning, they are neglecting their responsibilities" (p. 244). A paper by Dr D.R. Hanson (Leeds), The medical school - secular or Christian, brings much of what has been said, proposed, discussed and criticized so far, down to earth in the day to day practice of a medical faculty at a university. Prof. Jong 
Sung Rhee (Seoul) highlights this with a contribution from a Korean perspective.

A crucial problem for any university today, viz. Authority and discipline at institutions for higher education, is analysed by Prof. S.C.W. Duvenage (Potchefstroom) and Dr P.G. Schrotenboer (Grand Rapids). A considerable amount of thinking on this problem is still to be done, as the differences among the papers of Profs. Bingle, Hart, Duvenage and Dr Schrotenboer show but too clearly.

Academic freedom in Christian perspective by Prof. W. van't Spijker (Appeldoorn) presents an interesting analysis of current problems related to the freedom of scientific endeavour in recent times, and ends with a fairly traditional viewpoint on the Christian freedom of the Christian scholar. One can regard Prof. F.J.M. Potgieter of Stellenbosch's paper on the same topic as a curiosity, or one can condemn it outright. For anyone who attended the conference, the inclusion of this paper may serve to remind him of the most penetrating (however unscheduled) discussions of the whole conference which were sparked off by some rather archaic notions of race identity within the context of (Christian) scholarship.

The last number of papers may be described as a small compendium for the Reformed world of learning. From these papers one gathers a large amount of information on what is going on in the world of Reformed scholarship in Europe, the Americas, some parts of Africa, Australia and certain parts of Asia. Some of these papers deal especially with research on Calvin and the Calvinist tradition. A very illuminating paper in this respect is Prof. H.A. Oberman of Tübingen's Calvin's critique of Calvinism, which distinguishes between six different schools of Calvin interpretation, and outlines six relevant issues in recent scholarship on Calvin. Also in this vein is a paper by Dr R. Mokrosch (presently of Darmstadt) on The conflict between the Lutheran and Calvinistic churches about the relevance of faith for public life and the consequences of this conflict for Calvinistic research. A last paper by Dr D. Kempff (Potchefstroom) is a report On Calviniana literature.

This book is concluded by Resolutions of the conference, and an apt review and preview on the conference by Dr BJ. van der Walt. This collection of conference papers presents valuable data for an assessment of the position of Reformed Christian Scholarship in the late twentieth century.

\section{JJ. Snyman.}

